\title{
Mathematical Concept Understanding: the Impact of Integrated Learning Model
}

\author{
A.M.Irfan Taufan Asfar' ${ }^{1}$, Asmawaty ${ }^{2}$, A. M. Iqbal Akbar Asfar ${ }^{3}$, Aisyah Nursyam ${ }^{4}$ \\ ${ }^{1}$ Pendidikan Matematika, STKIP Muhammadiyah Bone \\ ${ }^{2,3}$ Program Doktoral Ilmu Pendidikan, Universitas Negeri Makassar \\ ${ }^{1}$ Correspondence Address; tauvanlewis00@gmail.com
}

\begin{abstract}
This study aims to investigate the improvement of students' mathematical concepts understanding through the application of Guided, Explained, Collaborated \& Evoked (GECE) Learning Strategy. The GECE Learning Strategy originates from the integration of the Auditory Intellectually Repetition (AIR) learning model and Guided Discovery learning model. The quasi-experimental with nonequivalent control group design was employed in this study. The instruments used were a test in the form of a description based on real-world concepts and a questionnaire to determine students' responses in the process of learning mathematics. Based on the results of hypothesis testing using the Mann-Whitney test, it was obtained that $\mathrm{p}<\alpha(0.001<0.005)$ which shows that the application of the GECE learning model affects students' mathematical concept understanding with n-gain of 0.62 (medium category). The effectiveness of the learning model applied was measured using Cohen's formula and a value of 1.88 (high category) was obtained. The results were also supported by positive students' responses of 3.45 which means that the integration of the Auditory Intellectually Repetition (AIR) learning model and Guided Discovery learning model could effectively improve students' mathematical concepts understanding.
\end{abstract}

Keywords: GECE; Learning Model Integration; Concepts Understanding

\section{INTRODUCTION}

One of the problems currently faced by national education nowadays is that the students in Indonesia cannot compete with students from other countries. TIMSS and PISA show that in general, the mathematical ability of Indonesian students is still low. The low mathematical ability is caused by several factors. One of them is the low ability to understand mathematical concepts (Asfar, Asfar, Darmawati, \& Darmawan, 2018). Concept understandings is an important component of studying mathematics (C et al., 2018), namely the ability to understand and master a subject matter by forming knowledge and to express in other forms that are easily understood (Septriani, Nicke, \& Meira, 2014) Concept understanding is a competency that students must have to understand the concepts and procedures of mathematics learning material (Rochaminah \& Anggraeni, 2016) because mathematics concepts are interconnected and mutually sustainable (Zevika, Yarman, \& Yerizon, 2012) Thus, to have a good mastery of mathematical concepts, students must understand the prerequisites concepts of the concepts being studied. In other words, one of the requirements to be able to understand the subject matter further is to understand the material being studied well.

Based on the problems, teachers are required to be more creative and innovative in the learning process so that students could be accustomed to construct their knowledge which ultimately will help them understand the concepts being taught. In learning, the teacher should choose and use approach strategies, methods, and techniques that enable students to learn, both mentally, physically, and socially. Besides the attitudes, emotions and lack of motivation from teachers, the selection of ineffective methods or strategies will result in the lack of students' conceptual understanding (Mansora, Lilia Halim, \& Osman, 2010). mathematics learning is by 
applying the GECE learning strategy (Guided, Explained, Collaborated \& Evoked).

Guided, Explained, Collaborated, and Evoked (GECE) learning strategy, is the result of the combined learning model of Auditory Intellectually Repetition (AIR) and Guided Discovery. The incorporation of these models is intended in the framework of innovative solutions due to the shortcomings or weaknesses of each model. Guided, Explained, Collaborated, and Evoked (GECE) is a learning strategy in the context of strengthening students' understanding of concepts through hearing and thinking ability by using guidance (assistance) in understanding and solving problems based on real-world concepts in groups that are active, meaningful, and fun.

Several previous studies have discussed how to apply the Auditory Intellectually Repetition learning model (AIR)and the Guided Discovery model (Agoestanto, Priyanto, \& Susilo, 2018; Anggoro, 2016; Asri \& Noer, 2015; Awaliyah, Soedjoko, \& Isnarto, 2017; Fitri \& Utomo, 2016; Imawan, 2015; Musfiroh, Susantini, \& Kuswanti, 2012; Muzaki, Slamin, \& Dafik, 2015; NO, 2016; Parno, 2015; Ramadhani, 2017; Sriwidiarti, 2016; Supriadi et al., 2018; Ungking \& Gamilina, 2018; Yusnita \& Subanti, 2014) and research in improving the concepts understand ability (Arrafat, 2014; Fahrudin, Netriwati, \& Putra, 2018; Fatqurhohman, 2010, 2016; Hidayat \& Nurrohmah, 2016; Kartika, 2018; Kurniawati, Hartanto, \& Zamzaili, 2017; Masitoh \& Prabawanto, 2016; Mustofa, Susilo, \& Muhdhar, 2016; Rahman, 2012; Rukmansyah, 2015; Septriani, 2014; Sri Hartati, Ilham Abdullah, 2017; Ulfaeni, Wakhyudin, \& Saputra, 2017) However, there is no research that integrates the Auditory Intellectually Repetition learning model (AIR) and Guided Discovery to improve concept understanding. Based on previous research, the renewal of this study is focused on the effect of learning models integration between the Auditory Intellectually Repetition (AIR) and Guided Discovery to enhance students' conceptual understanding. So, the purpose of this study is to test the effectiveness of the integration of the Auditory Intellectually Repetition (AIR) learning model and Guided Discovery learning model, hereinafter referred to as the GECE learning strategy.

\section{THE RESEARCH METHODS}

The research method used was quasi-experimental research with a non-equivalent control group design. The design used is almost the same as the pretest-posttest control group only design but, in this design, the sample is not chosen randomly (Sugiyono, 2017). The instruments used consisted of tests of students' mathematical concept understanding in the form of elaboration questions and questionnaires. The concept understanding test refers to the indicators of mathematical concepts understanding listed in the Ministry of Education's Director General of Primary and Secondary Education Regulation No.506 / C / Kep / PP / 2004 consisting of 7 abilities, namely (1) Restating a concept; (2) Classifying objects according to certain properties according to the concept; (3) Give examples and not examples according to concept; (4) Presenting concepts in the form of mathematical representations; (5) Developing the necessary/sufficient conditions for a concept; (6) Using and choosing certain procedures; and (7) Applying concepts/algorithms to mathematical solutions.(Hadi \& Kasum, 2015). Before the instruments were used, the test was tested for its distinguishing features of the questions and the level of difficulty as well as the validity and reliability of the questionnaire. Data analysis 
techniques used in this study included: normality test, homogeneity test, hypothesis test, gain normality test, and effectiveness test. The stages of the learning implementation can be seen in Table 1:

Table 1. Syntax of Guided, Explained, Collaborated, and Evoked (GECE) Learning Model

\begin{tabular}{cl}
\hline Steps & \multicolumn{1}{c}{ Description of Activities } \\
\hline Guided & $\begin{array}{l}\text { The teaching materials should have been given previously and the students } \\
\text { should have been instructed to learn at home. Each student sits with a } \\
\text { group that was formed at the previous meeting. The teacher gives a test in } \\
\text { the form of questions about the material to be discussed. Each group is } \\
\text { instructed quickly to do the questions. Then guiding its completion, this is } \\
\text { useful in equalizing students' perceptions before the material is explained. }\end{array}$ \\
\hline \multirow{3}{*}{ Explained The } & $\begin{array}{l}\text { The teacher gives a brief explanation by giving examples that are adapted to } \\
\text { students' daily lives. Students are instructed quickly to take notes from the } \\
\text { explanation presented by the teacher. }\end{array}$ \\
\hline Collaborated & $\begin{array}{l}\text { Each group has two diverse questions, the role of the group leaders are to divide } \\
\text { and guide group members in investigating the problem through discussion. The } \\
\text { leader of the group actively communicates and discusses so that the questions } \\
\text { discussed are more quickly resolved. The teacher appoints the names of students } \\
\text { who will be presenting. }\end{array}$ \\
\hline $\begin{array}{l}\text { Giving quizzes or games in the form of competitions to build student enthusiasm. } \\
\text { To facilitate the teacher in evaluating, the "Kahoot! Android application is used. } \\
\text { This application is motivating and fun because the students are challenged to } \\
\text { complete it and provide faster and transparent feedback on the achievement of } \\
\text { evaluation results. Not only students but the teachers are also required to quickly } \\
\text { provide the results of evaluations to students. }\end{array}$ \\
\hline
\end{tabular}

\section{THE RESULTS OF THE RESEARCH AND THE DISCUSSION}

Data description was performed on the students' mathematical concept understanding test scores obtained from the results of the pretest that was carried out before the treatment to determine the students' initial abilities and the posttest that was carried out after the treatment.

a. Pretest and Posttest Data

The data of the pretest and posttest in this study can be seen in Table 2.

Table 2. Pretest and Posttest Data

\begin{tabular}{ccccc}
\hline \multirow{2}{*}{ Description } & \multicolumn{2}{c}{ Experimental Class } & \multicolumn{2}{c}{ Control Class } \\
\cline { 2 - 5 } & pretest & posttest & pretest & posttest \\
\hline Average & 58.06 & 87.01 & 64.50 & 72.37 \\
Variance & 322.89 & 47.69 & 101.99 & 72.13 \\
Standard deviation & 17.97 & 6.91 & 10.10 & 8.49 \\
The lowest score & 0 & 71 & 36 & 54 \\
The highest score & 79 & 100 & 82 & 89 \\
\hline
\end{tabular}

Table 2 shows that the experimental group pretest obtains an average score of 58.06, the lowest score of 0 , the highest score of 79 , the variance of 322.89 , and the standard deviation of 17.97. The experimental group Posttest obtains an average score of 87.01, the lowest score of 71 , the highest score of 100 , the variance of 47.69 , and the standard deviation of 6.91 . Whereas, 
in the control group pretest obtains an average score of 64.50, the lowest score of 36, the highest score of 82, the variance of 101.99 and the standard deviation of 10.10. The control group posttest obtains an average score of 72.37 , the lowest score of 54 , the highest score of 89 , the variance of 72.13 and the standard deviation of 8.49 .

Based on the explanation, it can be concluded that the ability of the experimental class students taught using the GECE learning model is better than the students in the control class who were taught using Expository learning models.

\section{b. Data on Mathematical Concept Understanding}

The results of students' mathematical concept understanding were obtained from the pretest and posttest of the experimental and control class. The data for each indicator of students' mathematical concepts understanding can be seen in the following diagram.

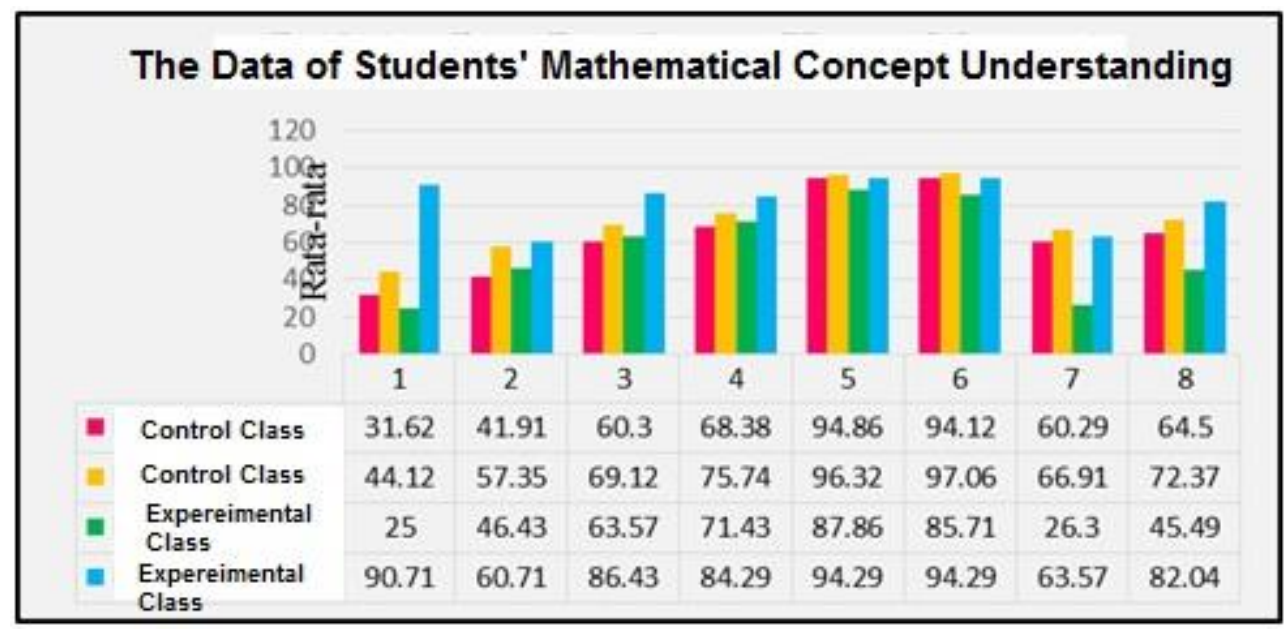

Figure 1. Average Score of Mathematical Concept Understanding Indicators

Based on Figure 1, the students' mathematical concept understanding ability in each indicator is as follows; (1) restating a concept in the control class obtains an average of 31.62 in the pretest and the average 44.12 in the posttest. Meanwhile, for the experimental class, the average score of the pretest is 25 and the average score of posttest is 90.71 ; (2) classifying objects according to certain traits of the concept, the average score of pretest in the control class is 41.91 and the average score of posttest is 57.35. Meanwhile, for the experimental class, the average score of the pretest is 46.43 and the average score of the posttest is 60.71 ; (3) providing examples and not examples of concepts, the average score of the pretest is the control class is 60.30 and the average score of posttest is 69.12. Meanwhile, for the experimental class, the average score of the pretest is 63.57 and the average score of posttest is 86.43 ; (4) presenting the concept in different forms of mathematical representation, the average score of pretest in the control class is 68.38 and the average score of posttest is 75.74. Meanwhile, for the experimental class, the average score of the pretest is 71.43 and the average score of the posttest is 84.29. (5) developing the necessary or sufficient requirements of a concept, the average score of pretest in the control class is 94.86 and the average score of the posttest is 96.32 . Meanwhile, for the experimental class, the average score of the pretest is 87.86 and the average score of the posttest is 94.29 ; (6) using, utilizing, and choosing certain procedures, the average score of 
preetest in the control class is 94.12 and the average score of posttest is 97.06 . Whereas, for the experimental class, the average score of the pretest is 85.71 and the average score of the posttest is 94.29 ; (7) applying the concept/algorithm on mathematical problem-solving, the average score of preetest in the control class is 60.29 and the average score of posttest is 66.91 . Meanwhile, for the experimental class, the average score of the pretest is 26.30 and the average score of the posttest is 63.57. (8) The overall average posttest score of the indicators of students' mathematical concepts understanding after the treatment is 72.37 in the control class and 82.04 in the experimental class. It means that the overall indicators of mathematical concepts understanding has increased. This shows that the mastery of mathematical concept understanding in the experimental class is better than the control class.

The results of the data analysis are based on inferential statistics start from the assumption test up to the hypothesis test and the analysis of student responses is described as follows.

a. Normality Test

A normality test was performed to determine whether the data of the two groups of samples are normally distributed or not. The normality test used in this study was the ShapiroWilk test with a significant level of $5 \%$. The analysis shows that the control class and experimental class data have $\mathrm{p}$-values $<0.05$, so it can be concluded that the data groups were not normally distributed.

\section{b. Homogeneity Test}

A homogeneity test is a statistical test conducted to find out whether both groups of samples have the same variance or not. The homogeneity of the two samples was performed using the Levene test assisted by SPSS software. Based on the analysis, it was obtained that pvalue $>\alpha$, so, it can be concluded that the data in this study have a homogeneous variance.

\section{c. Hypothesis Testing}

This test is carried out to find out whether the proposed hypothesis is accepted or not. The hypothesis test used in this study was Mann-Whitney because the data were not normally distributed. The results of the analysis are presented in Table 3.

Table 3.Hypothesis Test

\begin{tabular}{ccc}
$Z_{\text {observed }}$ & $\mathrm{P}$ & Result \\
\hline$-5,099$ & $<0,001$ & $\mathrm{H}_{0}$ is rejected \\
\hline
\end{tabular}

Based on the results of the hypothesis test, the p-value is $<0.05$ then, $\mathrm{H}_{0}$ is rejected. It means that the application of the GECE learning model is effective in improving students' mathematical concept understandings.

\section{d. Normality Gain Test}

This test was carried out to find out the magnitude of the increase in students' mathematical concept understanding. The results of the analysis can be seen in Table 4 .

Table 4. Normality Gain of Pretest-Posttest On the Experiment and Control Classes

\begin{tabular}{ccccccc}
\hline & \multicolumn{3}{c}{ Experimental } & & Control \\
\cline { 2 - 7 } & Pretest & Posttest & N-Gain & Pretest & Posttest & N-Gain \\
\hline$\sum_{\bar{X}}$ & 2031 & 2874 & 22 & 2189 & 2461 & 6,24 \\
\hline
\end{tabular}


Based on Table 4, it can be concluded that the average index gain of the mathematical concepts understanding ability is different between the control class and the experimental class. The average Gain index of the experimental class is 0.62 (medium category), while the average Gain index of the control class was 0.18 (low category).

\section{e. Effectiveness Test (Effect Size)}

Effect Size is an indicator that measures the magnitude of the effect of a treatment. The summary of effectiveness test results can be seen in Table 5.

Table 5. The Results of Effectiveness Test

\begin{tabular}{cccc}
\hline Class & Average & Variance & D \\
\hline Experimental & 87.01 & 47,687 & \multirow{2}{*}{1.88} \\
Control & 72.37 & 72,131 & \\
\hline
\end{tabular}

Based on Table 5, the magnitude of the effect due to the treatment using Cohen's formula $\mathrm{d}$ is 1.88 . This value is more than Cohen's proposed criteria $(\mathrm{d}>0.8)$. So it can be concluded that the effect of applying the GECE learning model is significant. This shows that the implementation of Guided, Explained, Collaborated, and Evoked (GECE) learning model is effective in increasing students' conceptual understanding.

\section{f. Student Responses}

To determine the responses after the application of the GECE learning model, the students were asked to fill in a questionnaire of responses consisting of 20 statements. The results of data analysis of students' responses toward the application of the GECE learning model in mathematics learning is 3.43 . This indicates that students tend to have a positive attitude towards learning mathematics by using the GECE model.

The concept's understanding ability is seen from the scores of the pretest and posttest. Based on the results of the pretest and posttest, the data obtained on derivative algebraic function material in the control class is 64.50 to 72.37 or increased by $7.87 \%$. The average score in the experimental class on the pretest is 58.06 to 87.01 or increased by $28.95 \%$. These results indicate an increase in the students' average concept of understanding ability in both classes. The category of improvement in the control class and the experimental class can be seen through n-gain results which are 0.62 or are in the medium category while the average $\mathrm{N}$-gain index in the control class is 0.18 or in the low category. Of the 7 indicators analyzed, the experimental class shows a better result than the control class in terms of the concept of understanding ability. These results indicate that the GECE learning model is better in developing students' concept understanding abilities.

The independent $\mathrm{t}$-test showed that the application of the GECE learning model was effective in improving students' concept understanding with $\rho<0.05$ with the effect magnitude of $d=1.88$. Also, the analysis of student responses after the learning process using the GECE learning model tends to be positive with an average score of 3.43. This positive response is one of the factors supporting the effectiveness of the GECE learning model that is applied to mathematics subjects. Thus, this proves that the GECE learning model is effective in increasing mathematical concepts understanding.

The GECE learning model is the result of the integration between Auditory Intellectually 
Repetition (AIR) and Guided Discovery. The incorporation of this model is intended in the framework of innovative solutions due to the shortcomings or weaknesses of each application. The AIR learning model is lacking in preparing problems. Students will have difficulty responding to the problems given and the make them anxious. The weaknesses of the AIR model are minimized by combining Guided Discovery learning model by giving problems related to daily examples or commonly experienced by students, dividing and facilitating students in groups to solve problems, and having group discussions that can give a sense of responsibility and confidence for students with high abilities to students low ability in sharing knowledge.

The Guided Discovery learning model has a weakness that it can only be applied on certain topics of mathematics, requires a relatively long time to apply, and difficult to use on students who are relatively slow in learning so that it can cause frustration in learning. The weaknesses of Guided Discovery learning model are minimized by the AIR learning model by providing the learning needed in every mathematics learning material so that the learning process not only trains students to solve problems creatively but also trains them in practicing hearing and encouraging them to argue or issue their ideas both in discussion activities between groups and to the teacher. The process of reconstructing knowledge is not only obtained from the teacher but from the process of sharing knowledge from among students so that it helps students who are low inability to understand concepts or procedures relatively quickly compared to the learning that relies solely on teacher guidance. The existence of repetition of learning in the form of assignments, quizzes, and games is expected to better train the students in using the knowledge gained in solving problems and train the memory of what they have learned.

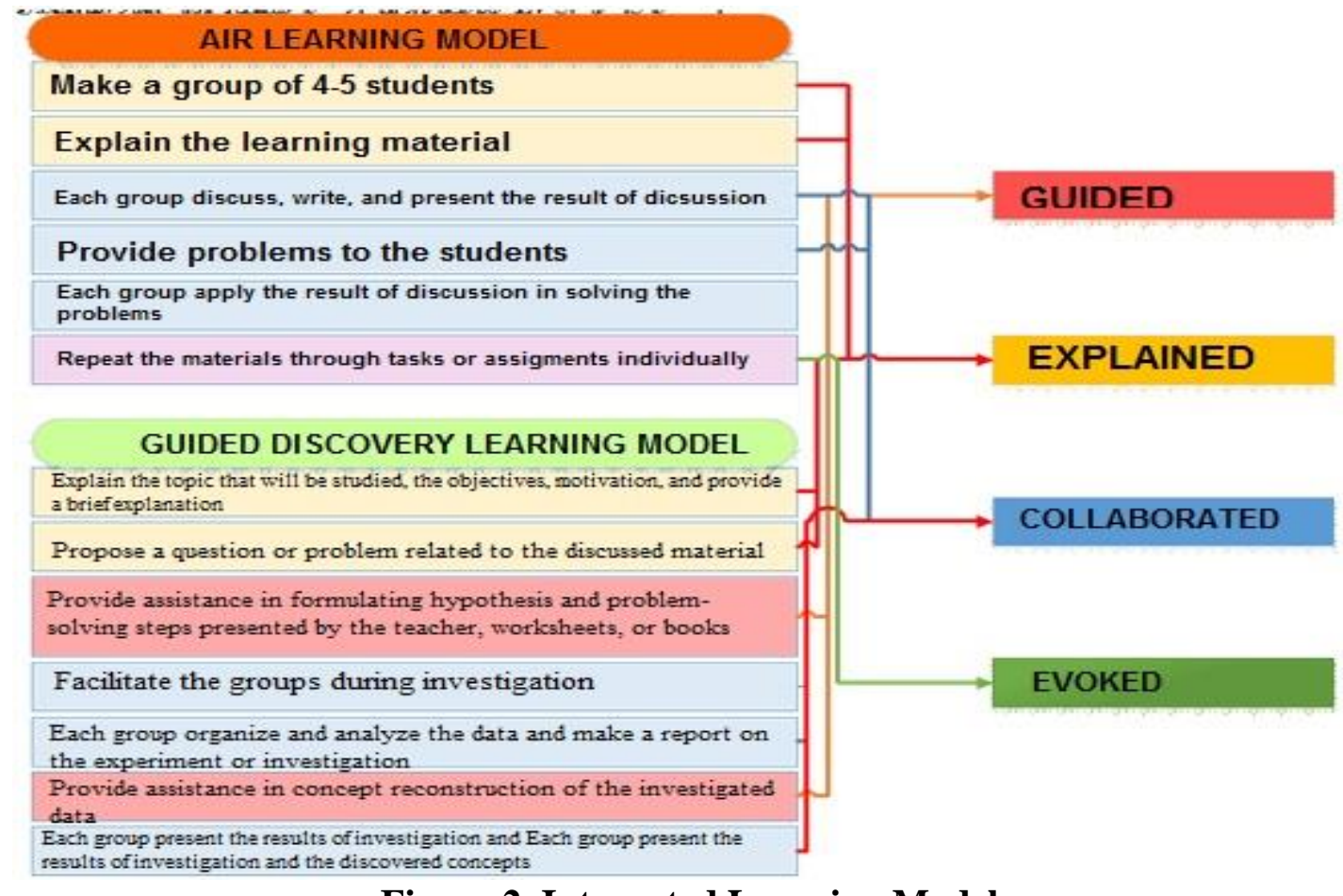

Figure 2. Integrated Learning Models 
Guided in the GECE learning model means providing guidance or assistance to be able to develop abilities independently in solving problems. The guidance is not only come from teachers but also from among students. Explained means learning must be through listening, arguing, expressing opinions, and responding. Collaborated means that learning must maximize the cognitive abilities of students in solving problems by connecting the knowledge they have with teaching material based on real-world concepts so that an exchange of ideas or solutions occurs. Evoked means to motivate students by giving challenges in the form of quizzes and competition games to arouse interest and motivation in learning.

GECE is a learning model in the context of strengthening students' understanding of concepts through hearing and thinking ability by using guidance (assistance) in understanding and solving problems based on real-world concepts in active, meaningful and fun groups. As proposed by Aydin (2014) that to achieve concept understanding, it is necessary to use a problem-based approach so that students find solutions to real-world concepts (real-world problems) presented by the group with the guidance of teachers which will affect the level of their careers in future. Therefore the GECE learning model is felt appropriate in accommodating the students' poor concepts understanding.

GECE learning model focuses on the construction of knowledge through questions related to students' daily lives or experiences so that they could better understand the concepts taught through the process of collaboration as well as the repetition that is useful to provide retention of knowledge. This is in line with the theory of constructivism that constructing knowledge is done by abstracting experiences as a result of student interaction with reality because the knowledge built based on reality will be relatively faster formed (Thobroni, 2015) This is in line with what was stated by Bruner and Piaget that in learning should pay attention to the experience, context, and complexity that allows extrapolation of student understanding (Asfar, AMIT, \& Nur, 2018) There is an element of collaboration in making discoveries as one of the strategies in maximizing participation and energizing learning by producing strong motivation in constructing knowledge (Lin, 2015) In addition, the existence of repetition in learning through quizzes allows cognitive action to occur in learning because, through the repetition of the exercises, the learning material will last longer.

Thus, the GECE learning model provides solutions in developing the ability to understand mathematical concepts through a systematic and directed process that prioritizes the knowledge construction process through collaboration, guidance, and strengthening the memory in the form of repetitions by giving tasks or quizzes that motivate students in learning. So that this learning model becomes a meaningful and fun alternative model to be applied in the learning process.

\section{CONCLUSION AND SUGGESTION}

Based on the results of hypothesis testing using the Mann-Whitney test, the results of $p$ $<\alpha(0,001<0,005)$ which indicate that the application of the GECE learning model influences the students' mathematical concept understanding with $\mathrm{N}$-gain of 0.62 (medium category). The effectiveness of the learning model was measured using Cohen's formula and obtained a value of 1.88 (high category) supported by a positive student response of 3.45 . It means that the 
integration of the Auditory Intellectually Repetition (AIR) learning model and Guided Discovery learning model effectively improves the understanding of the mathematical concepts.

Based on the findings obtained in this study, it is expected that the application of Guided, Explained, Collaborated \& Evoked (GECE) learning model could be more intensively used in mathematics learning so that students could better understand the concepts. It is also suggested for other researchers to examine other objects of students' example mathematical communication, problem-solving, critical-thinking, creative-thinking and so on through Guided, Explained, Collaborated \& Evoked (GECE) learning model.

\section{REFERENCES}

Agoestanto, A., Priyanto, O. Y. S., \& Susilo, B. E. (2018). The effectiveness of auditory intellectually repetition learning aided by questions box towards students' mathematical reasoning ability grade XI SMA 2 Pati. Unnes Journal of Mathematics Education, 7(1), $17-23$.

Anggoro, B. S. (2016). Meningkatkan Kemampuan Generalisasi Matematis Melalui Discovery Learning dan Model Pembelajaran Peer Led Guided Inquiry. Al-Jabar: Jurnal Pendidikan Matematika, 7(1), 11-20. https://doi.org/10.24042/ajpm.v7i1.23

Arrafat, Y. (2014). Pengaruh Penerapan Strategi Pembelajaran Aktif Tipe Index Card Match Terhadap Pemahaman Konsep Matematis Siswa Kelas VII SMPN 17 Padang. Jurnal Wisuda Ke 48 Mahasiswa Prodi Pendidikan Matematika, 1(1).

Asfar, A., Asfar, A., Darmawati, \& Darmawan, D. (2018). The Effect of REACE (Relating, Exploring, Applying, Cooperating and Evaluating) Learning Model Toward the Understanding of Mathematics Concept. In Journal of Physics: Conference Series ( $\mathrm{p}$. 12145).

Asfar, AMIT, \& Nur, S. (2018). Model Pembelajaran PPS (Problem Posing \& Solving). Sukabumi: Jejak Publisher.

Asri, E. Y., \& Noer, S. H. (2015). Guided Discovery Learning dalam Pembelajaran Matematika. In Prosiding Seminar Nasional Matematika dan Pendidikan Matematika (pp. 891-896).

Awaliyah, F., Soedjoko, E., \& Isnarto. (2017). Analisis Kemampuan Pemecahan Masalah Dalam Pembelajaran Model Auditory Intellectualy Repetition. Unnes Journal of Mathematics Education, 5(3), 243-249.

C, G., S, C., L, C., C, M., V, S., \& S, J. (2018). Understanding arithmetic concepts: The Role of Domain-Specific and Domain-General Skills. PLoS ONE Journal, 13(9).

Fahrudin, Netriwati, \& Putra, R. W. Y. (2018). Pembelajaran Problem Solving Modifikasi untuk Meningkatkan Kemampuan Pemahaman Konsep Matematis Siswa SMP. Desimal : Jurnal Matematika, 1(2), 181-189.

Fatqurhohman. (2010). Pemahaman Konsep Matematika Siswa Dalam Menyelesaikan Masalah Bangun Datar. Jurnal Ilmiah Pendidikan Matematika, 4(2), 127-133. 
Fatqurhohman, F. (2016). Pemahaman Konsep Matematika Siswa dalam Menyelesaikan Masalah Bangun Datar. JIPM (Jurnal Ilmiah Pendidikan Matematika), 4(2), 127-133.

Fitri, S., \& Utomo, R. B. (2016). Pengaruh Model Pembelajaran Auditory, Intellectually, And Repetition Terhadap Kemampuan Pemahaman Konsep Di SMP Pustek Serpong. Jurnal E-Dumath, 2(2).

Hadi, S., \& Kasum, M. U. (2015). Pemahaman Konsep Matematika Siswa SMP Melalui Penerapan Model Pembelajaran Tipe Memeriksa Berpasangan (Pair Cheks). Jurnal Pendidikan Matematika, 3(1), 59-66.

Hidayat, R., \& Nurrohmah. (2016). Analisis Peningkatan Kemampuan Pemahaman Konsep Matematis Siswa MTs Lewat Penerapan Model Pembelajaran Problem Based Learning Berbantuan Software Geogebra Berdasarkan Kemampuan Awal Matematika. JPPM, 9(1), $12-19$.

Imawan, O. R. (2015). Perbandingan Antara Keefektifan Model Guided Discovery Learning dan Project-Based Learning pada Matakuliah Geometri. PYTHAGORAS: Jurnal Pendidikan Matematika, 10(2), 179-188.

Kartika, Y. (2018). Analisis kemampuan pemahaman konsep matematis peserta didik kelas vii smp pada materi bentuk aljabar. Jurnal Pendidikan Tambusai, 2(58), 777-785.

Kurniawati, E., Hartanto, \& Zamzaili. (2017). Pengaruh Model Pembelajaran ARIAS INTEGRATIF Dan Kemampuan Awal Dalam meningkatkan Pemahaman Konsep dan Pemecahan Masalah Matematika Siswa SMP Di Kepahiang. Jurnal Pendidikan Matematika Raflesia, 2(2), 174-187.

Lin, L. (2015). Investigating Chinese HE EFL Classrooms: Using Collaborative Learning to Enhance Learning. Germany: Springer.

Mansora, R., Lilia Halim, L., \& Osman, K. (2010). Teachers' knowledge that promote students' conceptual Understanding. Procedia Social and Behavioral Sciences, 9, 1835-1839.

Masitoh, I., \& Prabawanto, S. (2016). Peningkatan Pemahaman Konsep Matematika dan Kemampuan Berfikir Kritis Matematis Siswa Kelas V Sekolah Dasar Melalui Pembelajaran Eksloratif. EduHumaniora: Jurnal Pendidikan Dasar, 7(2), 186-197.

Musfiroh, U., Susantini, E., \& Kuswanti, N. (2012). Pengembangan Modul Pembelajaran Berorientasi Guided Discovery Pada Materi Sistem Peredaran Darah. BioEdu, 1(2), 3740.

Mustofa, Z., Susilo, H., \& Muhdhar, M. H. I. Al. (2016). Penerapan Model Pembelajaran Problem Based Learning Melalui Pendekatan Kontekstual Berbasis Lesson Study Untuk Meningkatkan Kemampuan Memecahkan Masalah Dan Hasil Belajar Kognitif Siswa SMA. Jurnal Pendidikan: Teori, Penelitian, Dan Pengembangan, 1(5), 885-889.

Muzaki, L., Slamin, \& Dafik. (2015). Pengembangan Perangkat Pembelajaran berbasis Metode Guided Discovery Learning Berbantuan E-Learning dengan Aplikasi Atutor pada Pokok Bahasan Lingkaran. Pancaran, 3(2), 25-34. 
NO, I. N. (2016). Pengembangan Modul Berbasis Penemuan Terbimbing (Guided Discovery) Pada Materi Mempersiapkan Pertemuan/Rapat Pada Kelas XI APK di SMK Ketintang Surabaya. Jurnal Administrasi Perkantoran (JPAP), 4(3), 1-6.

Parno. (2015). Pengaruh Model Penemuan Terbimbing Dengan Strategi Self-Explanation Terhadap Prestasi Belajar Fisika Zat Padat Mahasiswa. Jurnal Pendidikan Fisika, 11(1), 23-35. https://doi.org/10.15294/jpfi.v11i1.4000

Rahman, A. (2012). Implementasi CTL dalam Meningkatkan Pemahaman Konsep Matematika Siswa. Journal Pendidikan Matematika UNP, 1(1).

Ramadhani, R. (2017). Kemampuan Pemecahan Masalah Matematika Siswa SMA Melalui Guided Discovery Learning Berbantuan Autograph. JPPM, 10(2), 72-81.

Rochaminah, S., \& Anggraeni. (2016). Perancangan Model Pembelajaran Sesuai Tuntutan Kurikulum 2013 Untuk Meningkatkan Pemahaman Konsep dan Keterampilan Berpikir Mahasiswa Calon Guru Matematika. Prosiding Seminar Nasional Matematika \& Pendidikan Matematika (SENDIKA), 2(2), 695-701.

Rukmansyah, E. T. (2015). Penggunaan Media Instan Dan Pendekatan Somatic Auditory Visual Intellectual (SAVI) Untuk Meningkatkan Pemahaman Konsep Kalor. Jurnal Pengajaran MIPA, 20(1), 43-47.

Septriani, N. (2014). Pengaruh penerapan pendekatan scaffolding terhadap kemampuan pemahaman konsep matematika siswa kelas VIII SMP Pertiwi 2 Padang. Jurnal Pendidikan Matematika, 3(3).

Septriani, Nicke, I., \& Meira. (2014). Pengaruh Penerapan Pendekatan Scaffolding Terhadap Kemampuan Pemahaman Konsep Matematika Siswa Kelas VIII SMP Pertiwi 2 Padang. Jurnal Pendidikan Matematika, 3(3), 17-21.

Sri Hartati, Ilham Abdullah, S. H. (2017). Pengaruh Kemampuan Pemahaman Konsep, Kemampuan Komunikasi Dan Koneksi Terhadap Kemampuan Pemecahan Masalah. JPM : Jurnal Pendidikan Matematika, 11(2).

Sriwidiarti, D. (2016). Keefektifan Metode Penemuan Terbimbing dan Metode Pemberian Tugas pada Pembelajaran Bangun Ruang Sisi Lengkung. Jurnal Pendidikan Matematika Dan Sains, 4(1), 63-74.

Sugiyono. (2017). Metode Penelitian Pendidikan (Pendekatan Kuantitatif, Kualitatif, dan $R \& D)$. Bandung: Alfabeta.

Supriadi, N., Syazali, M., Lestari, B. D., Dewi, E. S., Utami, L. F., Afriansyah, L., \& Putra, F. G. (2018). The Utilization of Project Based Learning and Guided Discovery Learning: Effective Methods to Improve Students' Mathematics Ability. Al-Ta'lim Journal, 25(3), 262-271.

Thobroni, M. (2015). Belajar \& Pembelajaran: Teori dan Praktek. Yogyakarta: Ar-Ruzz Media.

Ulfaeni, S., Wakhyudin, H., \& Saputra, H. J. (2017). Pengembangan Media Monergi ( 
Monopoli Energi) Untuk Menumbuhkan Kemampuan Pemahaman Konsep IPA Siswa SD. Profesi Pendidikan Dasar, 4(2), 136-144.

Ungking, N. W., \& Gamilina, P. (2018). Penerapan Model Auditory Intellectually Repetition (Air) Terhadap Aktivitas Dan Hasil Belajar Kognitif Siswa Sekolah Dasar. Keguru: Jurnal Ilmu Pendidikan Dasar, 2(2), 155-162.

Yusnita, R., \& Subanti, S. (2014). Pengembangan Perangkat Pembelajaran Berbasis Penemuan Terbimbing (Guided Discovery) Dengan Pendekatan Somatic, Auditory, Visual, Intellectual (SAVI) Pada Materi Pokok Peluang Kelas IX SMP Tahun Pelajaran 2013/2014. Jurnal Elektronik Pembelajaran Matematika, 2(4), 379-388.

Zevika, M., Yarman, \& Yerizon. (2012). Meningkatkan Kemampuan Pemahaman Konsep Siswa Kelas VIII SMP Negeri 2 Padang Panjang Melalui Pembelajaran Kooperatif Tipe Think Pair Share Disertai Peta Pikiran. Jurnal Pendidikan Matematika, 1(1), 45-50. 